\title{
The Food of the Hedgehog in England
}

\author{
D. W. YALDEN
}

\begin{abstract}
Yalden D. W., 1976: The food of the hedgehog in England. Acta theriol., 21, 30: 401-424 [With 4 Tables \& 1 Gig.].

The contents of 177 hedgehog (Erinaceus europaeus $\mathrm{L}$ in $\mathrm{n}$ a e u s, 1758) stomachs were analysed to ascertain the diet. The results are expressed in terms of percentage occurrence, percentage prey animals eaten, and percentage weight of prey eaten. On the weight basis, caterpillars, scarabeoid beetles and earthworms are the most important prey providing $55 \%$ of the food. Vertebrate prey is relatively unimportant, contributing perhaps $15 \%$ of the diet. So far as possible, the prey animals are identified to generic or specific level.

[Dept. Zool., Manchester Univ., Manchester, England]
\end{abstract}

\section{INTRODUCTION}

Although there is a considerable amount of general information available on the food of the hedgehog, Erinaceus europaeus, there has been very little systematic work. $\mathrm{Ka} \mathrm{la} \mathrm{bukhov}(1928)$ analysed the droppings or stomachs of 24 Erinaceus roumanicus ( $=E$. europaeus roumanicus $\mathrm{B}$ a r ret-Hamilto $\mathrm{n}, 1900)$ and 11 Hemiechinus auritus (G m e1 in, 1770) from the Ukraine and North Caucasus, collected throughout the summer. Shilova-Krassova (1952) analysed 262 droppings of $E$. europaeus from oak and pine forests in the Ukraine and southern Russia, nearly all collected in spring. In China, Li u (1937) analysed the stomach contents of $47 \mathrm{E}$. europaeus dealbatus (S w in hoe, 1870) from suburban areas, all collected in August. The fullest analyses, in terms of numbers and time-spread are those by Brockie (1959) and C a m p be 11 (1973 a, b) on the introduced E. europaeus in New Zealand; they examined material collected in a number of localities and at all times of the year. Brockie examined 10 stomachs and 90 droppings, while Campbell examined 60 stomachs and 230 droppings. Apparently the only systematic analysis of the food of hedgehogs in Western Europe is the limited study by $\mathrm{K} r \mathrm{u} \mathrm{u} \mathrm{k}$ (1964) of 33 droppings collected between March and June in the vicinity of the black headed-gull (Larus ridibundus) colony at Ravenglass, Cumberland. D i m e low (1963) used captive hedgehogs in feeding trials with a wide range of invertebrates. Hedgehogs have also been used, in experimental situations less directly 
relevant to the present work, by Cott (1951) and Lindemann (1952), while minor notes on the diet have been reported in many short papers (M of $f$ at, 1900; V a s a rhely i, 1960 etc.). The present account presents the results of the analysis of 177 stomachs of Erinaceus europaeus Lin n a e us, 1758 from England.

\section{MATERIAL}

The majority of the hedgehogs, 106, came from a single estate in East Anglia, situated on the Breckland. The estate manager has requested that the identity of the locality be withheld, and it will be referred to as "Estate L\& where necessary. The hedgehogs were trapped in cage and Fenn traps by the ten gamekeepers on the estate; in spring, they may operate $300-500$ traps, and have caught about 260 hedgehogs per annum during the 4 years 1966-1969. A further 43 hedgehogs came from various localities in Norfolk; some of these were also killed by gamekeepers, others were road casualties. In discussion, these may be grouped with the hedgehogs from Estate $\mathrm{L}$ as East Anglian hedgehogs. A further 25 hedgehogs came from scattered localities elsewhere in England, most of these were road casualties.

All this material was collected on behalf of Dr. P. A. Morris, for use in a general study of the hedgehog, and in particular for establishing methods of age determination (Morris, 1970). The stomachs were forwarded to me after preservation in formalin.

\section{METHODS}

The stomachs were dried, weighed and the contents tipped into a petri-dish of $70 \%$ alcohol with $5 \%$ glycerine. The empty stomachs were then re-weighed on a "Pesola s spring balance to give the weight of stomach contents, and any residue of contents adhering to the stomach wall washed into the petri-dish.

The material was sorted under a Prior binocular dissecting microscope with optional $20 \times$ objective lenses. Any fragments which could be used for identification or ennumeration of prey were preserved. For most insects, legs, wings, elytra or antennae were counted, millipedes were counted from the antennae but identified by their telson, while caterpillars were counted on pairs of mandibles, sets of legs or sets of prolegs. Arachnids had to be identified from parts of the prosoma, when possible, but their presence was readily indicated by limb fragments. The presence of soft bodied invertebrates was usually indicated by partor non-digested flesh, though limacid slugs were often indicated by shells and earthworms were sometimes only indicated by the presence of sand and chaetae. Counting these prey was sometimes impossible, though slugs could often be counted from the number of rather resilient "tails ", (the posterior tip of the foot). The presence of vertebrate prey was generally evident from fur or feathers, and eggshell usually indicated when birds' eggs had been eaten, though in four cases where this was suspected, no shell was present. Even so, it was assumed that eggs had been eaten.

The simplest method of presenting the results, used in all but one of the previous systematic studies of hedgehog food, is the percentage occurrence of prey items in the stomachs. This is also the most accurate presentation of the actual results. Since the stomach contents were searched routinely for items as small as separate millipede antennae, it is unlikely that anything of significance 
was overlooked. Unfortunately, this presentation is also, as many authors have pointed out, the most misleading. A single small arthropod occurring in twenty stomachs might show as a $20 \%$ occurrence, while twenty large arthropods in one stomach might be a $1 \%$ occurrence, though a much larger proportion of the diet. When the animal under study is able to eat a wide range of prey of very different sizes, some more quantitative approach is needed.

So far as possible, the numbers of individual prey animals have been counted; since individual prey animals are presumably what the hedgehog hunts, this approach has some value. It was impossible to count the earthworms, which therefore had to be omitted. A better idea of what constitutes the diet of hedgehogs is given by estimating the weight of different food ingested. Unffortunately, this method must also be the least accurate, compounding any errors of non- or mis-identification and miscounting with any errors in the weight values used for individual prey animals. For the arthropods and slugs, small numbers of preserved, whole, potential prey have been blotted dry and weighed, and the weights used to compute the total weight eaten of that type of prey. Details of these conversion factors are given in the systematic list of prey later in this paper. The quantities of earthworms, vertebrates and snails were estimated by blotting dry the identifiable, extractable prey and weighing that. Thus whereas errors in the estimated weights of arthropod prey eaten will be due to poor ennumeration and poor conversion factors, the errors for these non-arthropod prey will include also a fraction due to food which was too well digested for it to be removed and weighed. The weight of eggs eaten could only be estimated from the known weight of stomach contents. Despite these innaccuracies, the results are considered to be much more reliable an indication of the composition of the hedgehogs' diet; in principle this method of analysis is comparable with that used by Southern (1954) to investigate the diet of the tawny owl (Strix aluco).

\section{FOOD OF THE HEDGEHOG IN GENERAL}

\subsection{Percentage Occurrence}

Of the 177 stomachs examined, 40 were empty, and were ignored in computing percentage occurrences of the different prey. The most usual prey were carabid beetles, found in $60 \%$ of all the stomachs (Table 1). In all, Coleoptera occurred in $74 \%$ of the stomachs, with dung beetles and chafers (Scarabaeoidea), in $21 \%$ and other beetles, mostly weevils (Curculionidae) in $35 \%$. The next most usual items were earwigs (Dermaptera) $(58 \%)$ and caterpillars (larval Lepidoptera) $(49 \%)$. Earthworms, (Lumbricidae), slugs (Mollusca - Limacidae, Arionidae) and millipedes (Diplopoda, Iulidae) were also important items, but no other prey category occurred in more than $30(20 \%)$ of the stomachs. Vertebrate prey was not particularly common; mammal remains were found in only 16 stomachs $(12 \%)$, birds in $22(16 \%)$, and eggs in $15(11 \%)$. Moreover, these figures are certainly inflated by the habits of the gamekeepers who trapped many of the hedgehogs, for the traps are usually baited with rabbits, road-casualty hares, or addled eggs (manager, Estate L, pers. comm.). 


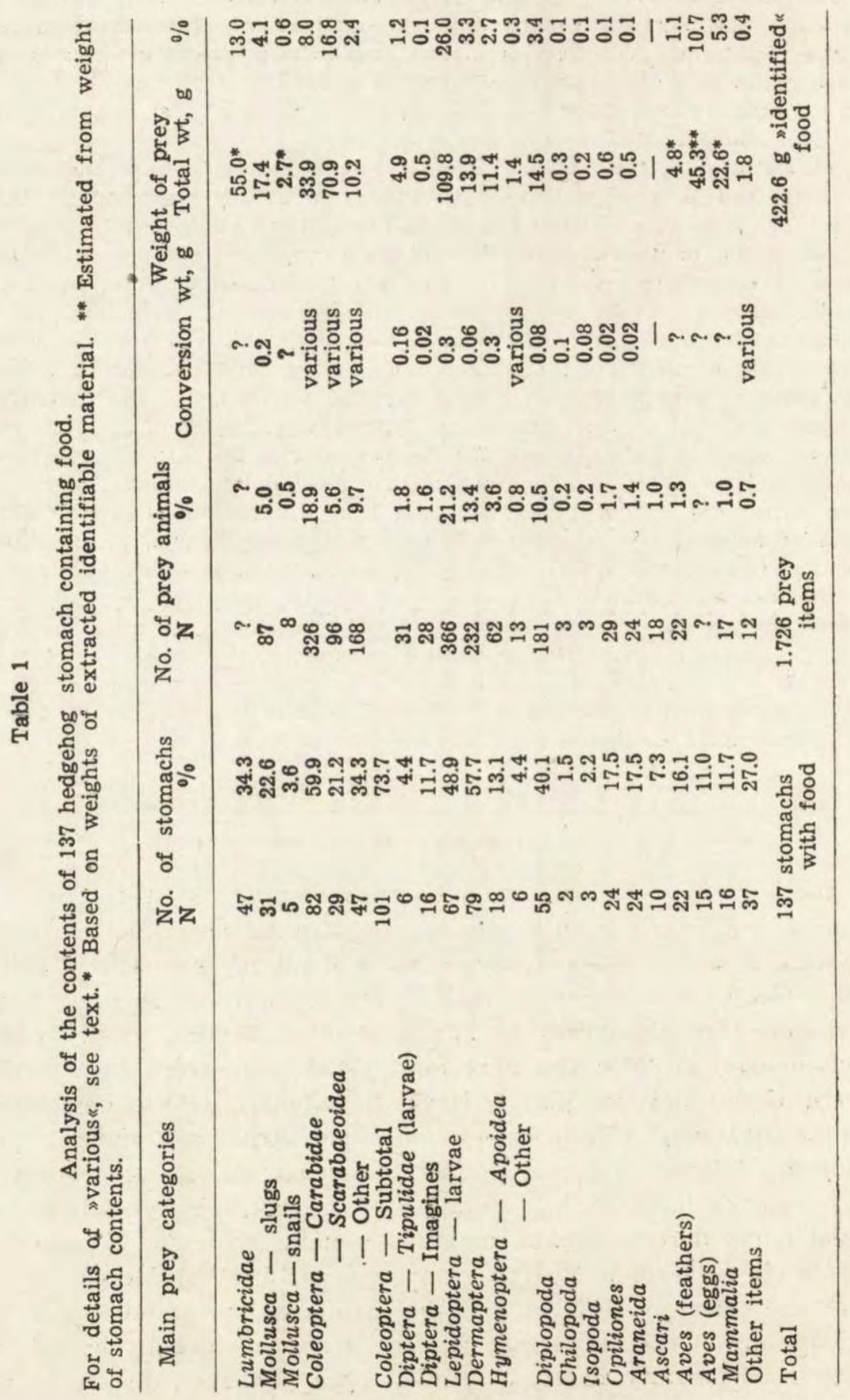




\subsection{Percentage Prey Animals}

Of the 1,726 prey animals identified (and not forgetting the unknown but large number of earthworms), most were caterpillars $(21 \%)$, with carabid beetles $(19 \%)$ occupying second place on this scale. Earwigs $(13 \%)$ and millipedes $(10 \%)$ were also numerically important. Slugs, bees, scarabaeoid and other beetles also made significant contributions to the number of prey, but many of the smaller animals, fairly important on a percentage occurrence basis, were seen to be unimportant numerically, as, apparently, were vertebrate foods.

\subsection{Percentage Weight of Food}

Analysed on this basis, the importance of caterpillars to the hedgehogs' diet is even clearer, for they contributed more than a quarter of the total identified weight of food. Scarabaeoid beetles were here the second most important component, a reflection of the large size of the individual beetles. Despite the large amount of digested or semi-digested material which was unaccountable, earthworms occupied thind place, contributing $13 \%$ of the weight of food. Carabid beetles, much lighter but more numerous than scarabaeoids, contributed $8 \%$ and the other groups of more important invertebrate prey, slugs, crane fly larvae, bees, earwigs and millipedes contributed $1-4 \%$ each. The insignificance of the minor items, spiders, harvestman, adult diptera, woodlice and centipedes, is further emphasized. The contribution made by the vertebrate prey is difficult to assess. Nearly all the occurrences of birds were based on the presence of a few feathers, so the small apparent contribution to the weight of the diet is to be expected. Equally, most mammal occurrences were of hair only, and the 22 grams came mostly from a single stomach containing a nearly complete wood mouse, Apodemus sp. The apparent importance of eggs in the diet is dubious. The figure derives entirely from three full stomachs, and was obtained by subtracting the estimated weight of all other components from the weight of stomach contents; whereas all other figures for the weight contribution of particular items are minima, the weight of contained egg is a maximum. These three stomachs came from Estate L; it could be argued either that the result vindicates the antipathy of the game keepers to hedgehogs, or that they had been baiting their traps with eggs.

The procedures used in this weight estimation accounted for about $422 \mathrm{~g}$ of food. This is about $62 \%$ of the figure of $674 \mathrm{~g}$ of stomach contents found by direct weighing. The error here is compounded from food which was too well digested to be weighed (earthworms and vertebrates especially), the weights of digestive juices, some minor com- 
ponents which have not been included (plant remains, bread, see later p. 418) and procedural error. The results for the slugs (see below) suggests that the error due to well digested food is the main component of the discrepancy.

An interesting sidelight from this is that only 18 of the stomachs examined contained over $10 \mathrm{~g}$ of food, and most contained less than $5 \mathrm{~g}$. Shilova-Krassova (1952) found the food consumption of some experimental hedgehogs to be about 100 Melolontha hippocastani per day; that would be about $100 \mathrm{~g}$ per day. $\mathrm{Kr} \mathrm{u} \mathrm{u} \mathrm{k} \mathrm{(1964)} \mathrm{carried} \mathrm{out}$ similar tests using chicks of Larus ridibundus, and suggested an average food consumption of $71 \mathrm{~g}$ per day, while Morris (1967) recommends a figure of $57 \mathrm{~g}$ por day for laboratory stock. The maximum amount found in any stomach was $32 \mathrm{~g}$ and that stomach was tightly filled. It would seem from this that the hedgehog must effectively fill its stomach twice each night, and that it must have a rather high rate of digestion.

\section{HETEROGENEITY WITHIN RESULTS}

It has been convenient so far to consider all the results together, but this is not entirely justified, for there is a certain amount of variation discernable within the sample. Possible variations due to the time of year, and to the sex, age, and source of the hedgehogs have been sought, analysing the data on a percentage occurrence basis.

\subsection{Variation through the Year}

Hedgehog stomachs were obtained throughout the warmer part of the year, from April to October, with a few specimens from November, December and January, but none from February or March, when almost all hedgehogs would be hibernating. All the January stomachs were empty while the single specimen from December contained a small amount of rodent fur, and these have been omitted from Table 2. It will be noted that the distribution of stomachs throughout the year is most uneven, with nearly half the sample coming from the two spring months of April and May when the gamekeepers were most active. There is a rather higher percentage of empty stomachs in the samples from the beginning and end of the year, perhaps indicating scarcity of food at these times. The high proportion of empty stomachs in August might be genuine, or reflect the small sample.

From the figures for percentage occurrence by month, most food items appear to vary little, or at best erratically, through the summer. The clearest indication of any systematic change of diet is seen in the caterpillars, which are apparently scarce in June and July, but more 


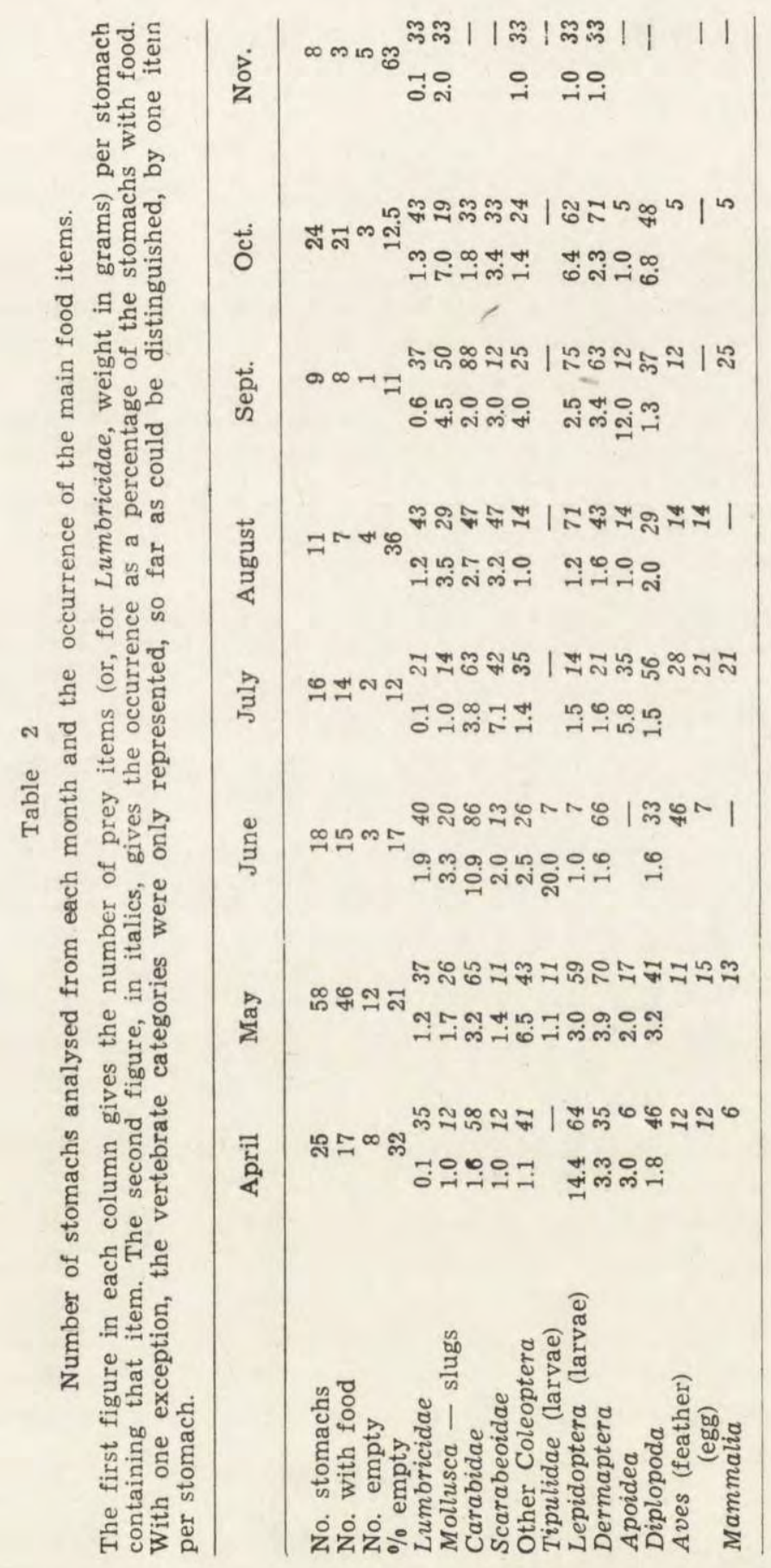


abundant at either end of the year, and in the scarabaeoid beetles which were more frequently eaten in July and August. Tipulid larvae were only taken in May and June.

The figures of the number of prey items per stomach containing that item are more illuminating. Earthworms are still rather erratically eaten throughout the year, with the amount per stomach varying between $0.1 \mathrm{~g}$ in April and July and $1.9 \mathrm{~g}$ in June, and the figures for bees fluctuate similarly, with the single September stomach containing 12 bees. Possibly these two items are affected by chance variations in weather (earthworms) or encounter (bees). Most of the other major invertebrate food items show clearer patterns of choice or availability, with moreover an indication of changing preference from month to month. In April, caterpillars are clearly important, with 14 per stomach. In May, "other " Coleoptera, i.e. weevils, become important, while in June, carabids, with 10.9 per stomach, are at a peak. (This figure is still 5 per stomach even if a single stomach with 85 beetles is ignored). From July through to October, scarabaeoid beetles are important items. In September and October, slugs seem to be taken in larger numbers, 7 per stomach in October, while millipedes are also most important in October. Earwigs seem to be taken in larger numbers in the spring and autumn months, less in the summer. Tipulid larvae, although apparently only available in June and July, may be taken in large numbers then. The occurrence of vertebrate prey seems to show no pattern at all.

\subsection{Variation with Sex or Age}

As most of the hedgehogs has been studied by Dr. Morris, sex and age data, the latter obtained from rings in the periosteal bone of the dentary (Morris, 1970) were available. The animals have been aggregated into younger animals (those in their first and second summers) and older animals (those in their third, fourth, fifth and sixth summers). Though there were some evident, mostly slight, differences between the first and second summer animals, splitting the sample this way provides two fairly equal sub-samples and also separates the immature animals and those only just mature (females at least usually breed in their second summer) from the more experienced older animals (Table 3 ). The first point to note is that, reassuringly perhaps, there are no major differences between the food taken by each sex. The minor discrepancies, of for example females taking carabids more often and eggs less often, are certainly not statistically significant.

The figures for the two age groups show rather greater difierences, and the original data for certain of these have been tested for statistical significance in $2 \times 2$ contingency tests. The older animals take earthworms 

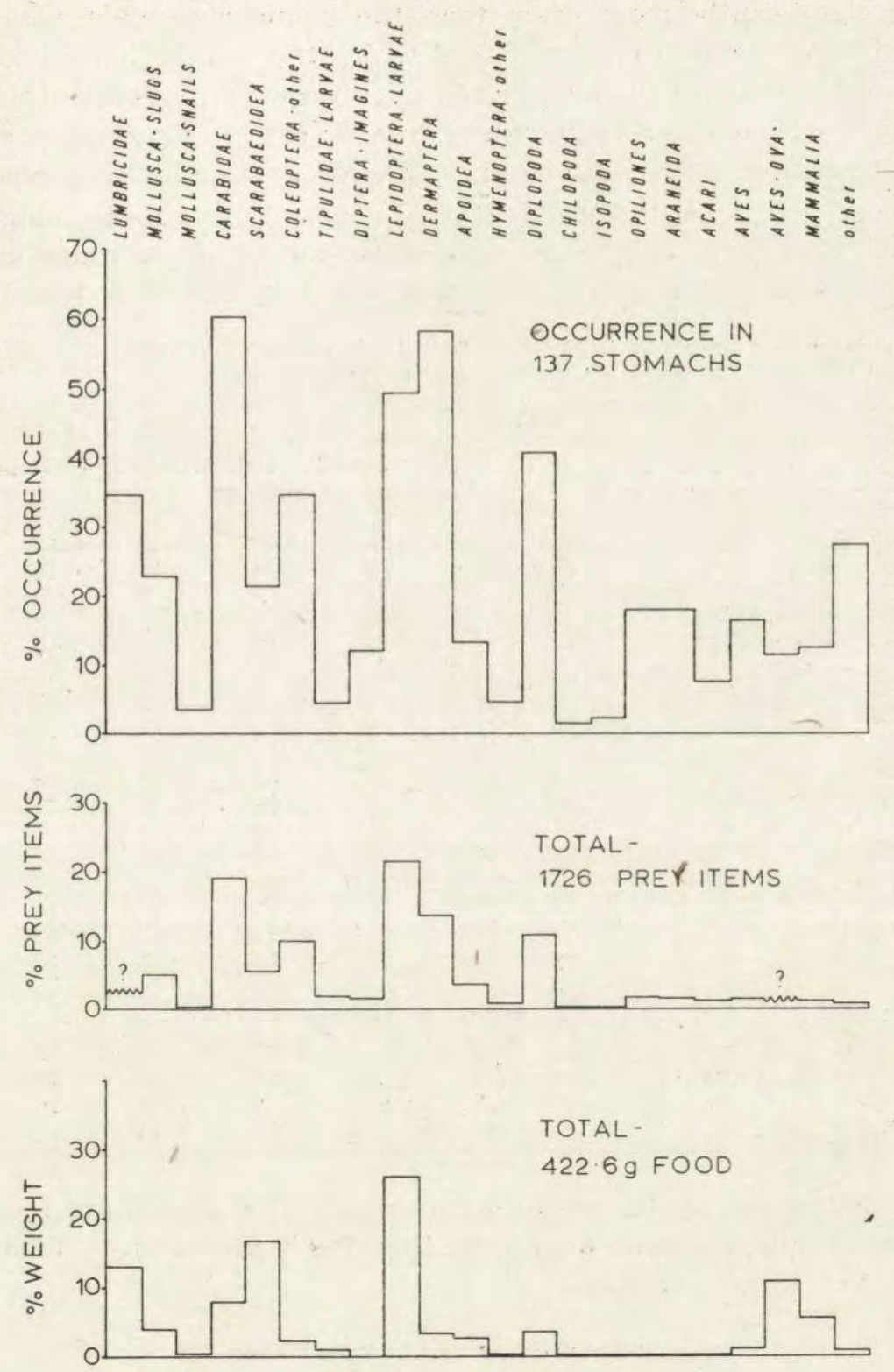

Fig. 1. Diet of the hedgehog Erinaceus europaeus, based on the analysis of 137 stomachs.

Data presented as percentage occurrence, percentage prey items and percentage estimated weight of food. Although carabid beetles and earwigs are the most frequently occurring items, the main weight of the diet is provided by caterpillars, scarabs and earthworms. 
$\left(\chi^{2}=4.4, p<.05\right)$, carabid beetles $\left(\chi^{2}=8.37, p<.01\right)$ and slugs $\left(\chi^{2}=7.6\right.$, $p<.01)$ significantly more often than the younger animals. One might expect there to be some items of food which the younger ones take more often, but there are no statistically significant differences: One must suppose then that older and younger animals eat the same range of food, but that each older individual, either through greater hunting experience or perhaps just through a higher stomach capacity, is able to sample that range of food more fully. The only slight indication of more frequent

Table 3

Percentage occurrence of food categories in stomachs of hedgehogs of different sex, age and provenance.

\begin{tabular}{|c|c|c|c|c|c|c|c|}
\hline & \multicolumn{2}{|c|}{ Sex } & \multicolumn{2}{|c|}{ Age } & \multirow{2}{*}{$\begin{array}{c}\text { From } \\
\text { Estate L }\end{array}$} & \multirow{2}{*}{$\begin{array}{c}\text { From } \\
\text { Norfolk }\end{array}$} & \multirow[t]{2}{*}{ Rest } \\
\hline & $0^{7}$ & q & $\begin{array}{l}\text { 1st \& } 2 \text { n } \\
\text { summer }\end{array}$ & $\begin{array}{l}\text { d } 3 r d \\
\text { summer }\end{array}$ & & & \\
\hline Lumbricidae & 36 & 35 & 27 & 46 & 33 & 37 & 47 \\
\hline Mollusca - slugs & 21 & 24 & 13 & 34 & 18 & 17 & 59 \\
\hline - snails & 5 & 2 & 3 & 5 & 5 & - & 6 \\
\hline Coleoptera - Carabidae & 56 & 67 & 49 & 75 & 58 & 63 & 76 \\
\hline - Scarabaeoidea & 23 & 22 & 20 & 25 & 26 & 17 & 12 \\
\hline - Other & 34 & 35 & 28 & 41 & 40 & 23 & 24 \\
\hline Diptera - Tipulídae (larvae) & 6 & 2 & 1 & 8 & 2 & 3 & 18 \\
\hline - Imagines & 13 & 11 & 11 & 15 & 14 & 10 & 6 \\
\hline Lepidoptera (larvae) & 49 & 50 & 44 & 54 & 57 & 37 & 29 \\
\hline Dermaptera & 59 & 61 & 52 & 67 & 59 & 60 & 65 \\
\hline Hymenoptera - Apoidea & 14 & 13 & 10 & 18 & 14 & 10 & 18 \\
\hline - Other & 4 & 6 & 6 & 3 & 4 & - & 18 \\
\hline Diplopoda & 36 & 46 & 38 & 44 & 46 & 37 & 24 \\
\hline Opiliones & 15 & 22 & 15 & 20 & 19 & 10 & 24 \\
\hline Araneida & 20 & 17 & 17 & 21 & 24 & 10 & 12 \\
\hline Aves - feather & 16 & 17 & 18 & 15 & 15 & 23 & 12 \\
\hline - eggs & 14 & 9 & 14 & 10 & 12 & 13 & 12 \\
\hline Number with food & 80 & 54 & 71 & 61 & 84 & 30 & 17 \\
\hline Number empty & 24 & 15 & 19 & 19 & 18 & 16 & 5 \\
\hline$\%$ empty & 23 & 22 & 21 & 24 & 18 & 35 & 23 \\
\hline$\%<5$ g. stomach contents & 64 & 70 & 73 & 59 & 64 & 73 & 71 \\
\hline$\% 5-10 \mathrm{~g} . \quad "$ & 15 & 15 & 14 & 16 & 18 & 10 & 6 \\
\hline$\%>10 \mathrm{~g}$. & 15 & 11 & 7 & 20 & 13 & 13 & 12 \\
\hline
\end{tabular}

prey consumption by the young animals is in the vertebrate food; possibly the young animals, unable to find fresh invertebrate food, must tolerate vertebrate carrion.

\subsection{Variation due to Provenance}

The small sample of hedgehogs from outside East Anglia necessarily limits the possible comparisons, but the correspondence is in any case fairly close, with one major exception. East Anglian hedgehogs eat very few slugs compared with those from the rest of England and the difference is highly significant $\left(\chi^{2}=12.03, p<.001\right)$. 


\section{COMMENTS ON THE PREY ANIMALS}

The interest of my invertebrate-zoologist colleagues in this work has indicated that precise identification of the prey species selected by predators would be appreciated. Considerable efforts were therefore made to identify the prey species to generic or specific levels. These details will be considered in this section, and compared with those of other workers. In addition, some explanation of the weight correction factors used in compiling table 1 is given here.

Oligochaeta, Lumbricidae

Earthworms were not only difficult to quantify in any way, but also very difficult to identify. In 17 stomachs, their presence was only indicated by chaetae, and there is no way, at present, of identifying these. The standard key (G e r r a r d, 1964) requires the complete anterior part of the worm, back to the clitellum, and the present specimens were rarely that complete. One stomach, containing $14 \mathrm{~g}$ of recognisable earthworms, contained at least 2 Lumbricus terrestris, and probably all were that species. Another, with nearly $9 \mathrm{~g}$ of earthworm, contained at least one large Allolobophora species. Practically all the worms found were large specimens, so belonged to one of these two genera. Since $L$. terrestris habitually comes onto the surface of the ground at night, it would be particularly susceptible to hedgehog predation. Brockie (1959) presumed that the earthworms eaten by his hedgehogs were $L$. terrestris; C a mp bel1 (1973a) however recorded A. caliginosa in the diet of her hedgehogs.

Mollusca, Gastropoda

Slugs, - Limacidae and Arionidae. Of the 87 slugs, 52 were certainly or probably Agriolimax reticulatus, while other species identified included Arion hortensis (1), Arion circumscriptus (probably 4), and 5 small Arion sp.; Limax maximus (3); and 5 Milax sp. probably including $M$. gagates and $M$. budapestensis. B rockie (1959) and C a m p bll (1973a) also found Agriolimax reticulatus to be the species usually eaten.

The small Agriolimax reticulatus was the main prey slug; a small specimen of Agriolimax about $12 \mathrm{~mm}$ long (contracted) weighed $0.2 \mathrm{~g}$, and this was used as the conversion factor. This gives an estimate of $17.4 \mathrm{~g}$ of slugs eaten in total, may be compared with the direct weight of identifiable slug remains of $9.25 \mathrm{~g}$.

Snails - Helicidae. Only 8 individual snails were encountered, and of these, one was probably Helix aspersa, and the rest either Arianta arbustorum, H. (Cepaea) nemoralis, or H. (C.) hortensis. 


\section{Coleoptera}

Carabidae. Among the 326 adult carabids eaten by these hedgehogs, the largest number were Harpalus (Pseudophonus) rufipes (=P. pubescens, and so called by Dimelow 1963); 136 of this species were counted, 75 of them in one stomach. In all, 40 Pterostichus sp. (=Feronia sp.) were found, probably $P$. madidus or P. melanarius; 10 of them were in the stomach containing $75 \mathrm{H}$. rufipes. Of the larger carabids, 8 Carabus sp. (at least one C. granulatus, and the rest probably C. violaceus, or C. nemoralis) and 4 Cychrus rostratus were recorded. The absence of the fairly large and common Abax parallelopipidus (=A. ater) was surprising, particularly as Dim elow (1963) demonstrated its acceptability. Other specimens identified included 35 Nebria sp. (presumably $N$. brevicollis), 3 Loricera pilicornis, 7 Harpalus aeneus, 41 Leistus sp. (L. ferrugineus or L. rufescens), 2 Amara communis and 1 Clivina sp.

In computing the weights for table 1 , Carabus sp. were taken as $0.6 \mathrm{~g}$ each, Cychrus $0.2 \mathrm{~g}$, Pterostichus sp. and Harpalus rufipes $0.14 \mathrm{~g}$ and all the other carabids as $0.04 \mathrm{~g}$ each. These weights were all derived from weighing small numbers of alcohol-preserved specimens of appropriate genus and size.

Scarabaeoidea. Of the 96 individual scarabs found, the largest number of any one species was Serica brunnea, of which 41 were identified. These occurred in only 3 stomachs, all from hedgehogs killed in July, and one stomach contained 25 individuals. 35 Geotrupes sp. were found, distributed between 12 stomachs, with up to 12 beetles in one stomach. These were probably all $G$. stercorarius, from their size and the characters of the tibiae, but it is difficult to be certain; they were eaten from August to October. In addition, there were 4 specimens of Melolontha melolontha (all eaten in May), 2 Amphimallon solstitialis (June) and 12 Aphodius sp. (June - September). Shilova-Krassova (1952) found Melolontha hippocastani (a species not found in southern England) to be the predominant prey of her hedgehogs, with an $83 \%$ occurrence in her samples. C a m p bell (1973a) found Costelytra zealandica adults to be main item of food during the flying season, and Odontria striata also occurred. B r ockie (1959) only mentions one adult scarab among the prey of the New Zealand hedgehogś, the native Pyronota festiva. However, he also mentions larval Costelytra zealandica as an item of food, and S hilova$\mathrm{K}$ r a s s ova (1952) found unidentified scarabaeoid grubs in $9 \%$ of her samples. Such larvae were not found in the present analysis, though D im elow (1963) also demonstrated the acceptability of $M$. melolontha larvae. In computing the weights of scarabs for table 1, Melolontha were taken as $1.3 \mathrm{~g}$ each, the mean weight of 5 preserved specimens. The 
specimens of Geotrupes were closer in size to individuals of G. stercorarius and $G$. spiniger, weighing $1.1 \mathrm{~g}$ and $1.4 \mathrm{~g}$ respectively, than to 7 Scottish specimens (also G. stercorarius) which only weighed $0.3 \mathrm{~g}$ each, so a conversion weight of $1.2 \mathrm{~g}$ was used. Weights of $0.5 \mathrm{~g}$ for Serica and $0.2 \mathrm{~g}$ for Aphodius and Amphimallon were used, based on preserved scarabs of appropriate size.

Other Coleoptera. Of 168 other beetles, the majority (117) were probably or certainly the single otiorrhynchine species Philopedon plagiatus. Since this is a fairly small insect, it would have been an unimportant source of food, but for two stomachs which contained respectively 56 and 23 individuals. 12 specimens of Necrophorus were recovered including $2 \mathrm{~N}$. humato ${ }^{2}$ and $7 \mathrm{~N}$. investigator, and 3 specimens of Phosphuga attrata (all Silphidae). The only other beetles identified were two small Cholevidae and 25 minute Staphylinidae. The absence of larger staphylinids was surprising, as the only "other Coleoptera " tested by Dimelow (1963) and found to be acceptable, was Staphylinus olens, the large devil's coach-horse. Kalabukhov (1928) mentions that the tenebrionid Blaps mortisaga occurred quite frequently; this particular species is rare in Britain, though other tenebrionids are common enough. In New Zealand, B rockie (1959) found the native cerambycid Oemona hirta to be the most usual beetle prey, and also mentions the large huhu, Prionoplus reticularis (also Cerambycidae) as an item of diet.

The conversion weights used for these items were derived indirectly, by comparison with the weights of carabid and scarabaeoid beetles of appropriate size. Philopedon is a fairly large curculionid and was taken as $0.05 \mathrm{~g}$ each, while the silphids were taken as $0.25 \mathrm{~g}$ each.

\section{Diptera}

Crane fly larvae, Tipulidae, occurred infrequently, but were evidently important to the few hedgehogs which had eaten them, with up to 20 in one stomach. Two pupae of Tipulidae were also recorded. No attempt was made to identify these to specific level. A mean weight of $0.16 \mathrm{~g}$ was used, based on the weights of seven intact specimens from two of the stomachs.

The 23 adult Diptera recorded were obviously of no importance to the diet of the hedgehog. A single specimen of Mesembrina meridiana (Muscidae) and ten specimens of a cordylurid with characteristic green femora and yellow tibiae, presumably Cordylura sp., were among these, but the other individuals were mostly very small, Drosophila-sized, flies, probably ingested accidentally.

Fly eggs or very small maggots occurred in 9 stomachs. In two cases 
they were associated with vertebrate remains, and may indicate feeding on carrion; this may be the explanation for the other cases as well.

Of other workers, Liu (1937) found that 754 larvae of Chrysomyia, 330 of Musca and 35 of Eristalis constituted $95 \%$ of all the food items identified; his hedgehogs were hunting around latrine pits. $\mathrm{C}$ a $\mathrm{m} \mathrm{p} \mathrm{b}$ e 11 (1973) found adult Sarcophaga milleri in $32 \%$ of dropping, and dipteran larvae occasionally.

\section{Lepidoptera}

Caterpillars, which constituted the main prey of the hedgehogs, are notoriously difficult to identify; most identifications rely on external colouring, and there are no scientific keys. However, almost all of the 366 caterpillars seemed to be Agrotidae (Noctuidae). Further, all but about a dozen were of one colour and mandible type, and closely comparable with Amathes xanthographa (Square-spot Rustic). This is a species which feeds on grasses, among other plants, from August overwinter to May - it would therefore be fully grown in the spring when most of these caterpillars were eaten. Fragments of finely chewed grass were frequently associated with caterpillars in the stomachs. A few specimens looked like Apamea monoglypha (Dark Arches). A maximum of 63 caterpillars was found in one stomach. Only Brockie (1959) and C a m pbell (1973a) of the other students found caterpillars to be a significant prey item. B r o c ki e (1959) only named one species, Pseudaletia seperata (=Leucania seperata), another grass-feeding agrotid allied to the British wainscot moths, which was eaten mainly in late summer and autumn. Campbell (1973a) however found that the larvae of, probably Wiseana (a hepialid) were the second most frequent prey.

A single adult lepidopteran, also Agrotidae, and three lepidopteran pupae were recorded. Brockie (1959) reported numerous newly emergent adults of Pseudaletia seperata in one dropping, and fragments of moth wings in other specimens, while C a m p bell (1973a) recorded adult Wiseana in $3 \%$ of droppings, but considered them underrecorded.

Pieris larvae of various sizes weighed from 0.14 to $0.3 \mathrm{~g}$, a small Cerapteryx larvae $0.2 \mathrm{~g}$, and a fully fed Cerapteryx $0.5 \mathrm{~g}$; a conversion weight of $0.3 \mathrm{~g}$ was therefore used.

\section{Dermaptera}

The frequency with which earwigs were eaten was something of a surprise, since casual inspection of leaf litter does not often reveal them, and Bornebusch (1930) considered them rather unimportant members of the litter fauna. As 22 occurred in one stomach, they may be quite an important source of food to the hedgehog. So far as could 
be ascertained, all 232 specimens were Forficula auricularia, the common earwig; as the distinctive tarsus was the most easily recognisable fragment, the generic identity at least is fairly certain.

5 preserved specimens of $F$. auricularia weighed about $0.06 \mathrm{~g}$ each, and this was used as the conversion weight.

\section{Hymenoptera}

Hymenopterans occurred in 20 stomachs, and of the 62 individual prey, 38 were bumble bees, Bombus sp. No attempt was made to identify these specifically. Most of the occurrences were of single bees, but one stomach contained 13 bees and 29 coccoons and another had 13 bees and 15 coccoons. In these instances the hedgehogs had obviously raided nests, the rest were probably found comatose. 11 specimens of Apis sp. were recovered, 8 of them from one stomach, and a single Vespa sp. There were also 9 ants, including 7 Formica lehmani and a single Lasius alienus, and one ichneumon Hemiteles sp.

The mean weight of 5 preserved Bombus workers was $0.3 \mathrm{~g}$ and of 10 Apis was $0.12 \mathrm{~g}$. These were used as conversion weights, the latter figure also applying to the Vespa.

Diplopoda

With an occurrence rate of $40 \%$, millipedes were obviously a fairly important item of the diet, despite their low weight, and one stomach contained 27 individuals. Specific identifications were rather difficult, as most specimens were thoroughly chewed. Apart from a single specimen of Glomeris marginata, all 181 individuals belonged to the Iulidae. Counts of these, based on antennae, were fairly straightforward, and a certain amount of further identification was possible using the shape of the telson, thanks to the diagrams given by Blower (1958). Among the iulids there were 27 Schizophyllum sabulosum, 11 Cylindroiulus sp. (including $4 \mathrm{C}$. londinensis and $2 \mathrm{C}$. punctatus), 1 Tachypodoiulus niger, 1 Iulus scandinavius and a further 30 telson of Iulus/Ophyiulus/Leptoiulus type which were quite possibly, on size, also Iulus scandinavius.

The complete absence of polydesmid millipedes is a little surprising, since Dimelow (1963) showed that three species of Polydesmus were quite acceptable, and $P$. angustus is among the commonest of British millipedes.

B r o ckie (1959) also found millipedes to be of frequent occurrence in the hedgehog diet, and mentions that some droppings contained nothing else. While he did not identify any directly, he presumed that they were mostly the introduced species Cylindroiulus brittanicus and Ophyiulus pilosus, as these were the most abundant millipedes locally. 
The mean weight of an assortment of 10 iulids was $0.08 \mathrm{~g}$ and this was used as the conversion weight for table 1 .

\section{Chilopoda}

Only three single centipedes were found, in two stomachs. They appeared to be single specimens each of the geophilomorphs Geophilus carpophagus, G. electricus and $G$. osquidatum.

\section{Isopoda}

Only three individual, very chewed, woodlice were found in these stomachs, though Brockie (1959) and Camp bell (1973a) reported small amounts of Porcellio scaber in $11 \%$ and $17 \%$ respectively of the droppings analysed. Dimelow (1963) reported rather low rates of acceptance (by the standards of her tests) for all the species she tested, among them $P$. scaber $(65 \%$ acceptances), Oniscus asellus $(69 \%)$, Philoscia muscorum $(43 \%)$ and Armadillidium vulgare $(89 \%)$. It would seem that woodlice are genuinely ignored by hedgehogs.

\section{Opiliones}

Although harvestmen occurred in $17 \%$ of the stomachs, there were only from 1 to 3 in each case, and they are so light that they contributed virtually nothing to the diet. All those identified belonged to the Phalangiidae, and certain or probable identifications included Mitopus morio (5), Platybunus triangularis (2), Lacinius ephippiatus (2), and single specimens of Odiellus spinosus, Oligolophus hanseni, Oligolophus agrestis and Phalangium opilio.

\section{Areneida}

Spiders were likewise an insignificant item of diet, with only a single specimen in each of 24 stomachs. All of the 8 cases where more than limb traces were present were wolf spiders Lycosidae, either Lycosa sp. or Trochosa sp., which family C a m p bell (1973a) also recorded frequently.

\section{Acari}

About 18 mites were noted in all, coming from 10 stomachs. Of these 3 were in association with Geotrupes, 3 with Necrophorus and 1 with Aphodius. Presumably, then, the mites were phoretic specimens eaten accidentally with the prey. Camplo 11 . (1973a) recorded orabatid mites on 8 occasions.

\section{Other Invertebrata}

A number of occurrences which were included in Table 1 under "other" have already been mentioned above - adult and pupal Lepi- 
doptera, the coccoons of Bombus, and eggs and small larvae of Diptera. Other occasional items included 2 small Collembola, 4 hedgehog fleas (Archaeopsylla erinacei), one grasshopper (probably Omocestus) and four Hemiptera. One hemipteran was a minute psyllid, the others were froghoppers, Cicadomorpha. Five stomachs which were virtually empty contained numbers of minute thread-like Nematoda.

\section{Vertebrata}

The importance of vertebrate food to hedgehogs is one of the most controversial issues. None of the present sample contained remains of Amphioia or Reptilia, though the ability of the hedgehog to tackle the adder (Vipera berus) is almost legendary (H erter, 1965). Shilova$\mathrm{K}$ ras s ova (1952) recorded the occurrence of snake once, and lizards, all Lacerta sp., 16 times. K a la b u khov (1928) reported 4 occurrences of the lacertid lizards Lacerta agilis and Eremias arguta. B rockie (1950) found remains of the introduced frog Hyla aurea in $14 \%$ of his sample.

Bird remains, mainly feathers, were found in 22 stomachs, but it is not certain that all of these represented avian prey. For instance, one stomach containing 4 feathers also contained a bumble bee, Bombus, nest; it is at least possible that the feathers were nest lining. An attempt was made to narrow down the range of birds which might have been eaten by reference to the feather characters given by D a y (1966). This was not very easy, as not all the feathers from a bird's plumage possess the appropriate taxonomic characters. In three cases, the feathers came definitely from a galliform bird, as the characteristic double nodes were seen; in two other cases, the bird may have been galliform, but double nodes were not seen, and in another case the remains of what was probably a gamebird chick were found (chick down feathers are not diagnostic). In two cases the bird was probably passeriform, and there were single cases each of probable Columbiformes and Falconiformes. This accounts for 10 cases of bird remains and leaves 12 unexplained. One of these contained a small amount of flesh and a few feathers sin pin "; and another contained a claw (? chicken), all the rest were of one to a few feathers.

Shilova-Krassova (1952) found a single occurrence of bird prey, and $\mathrm{Kalabukhov}$ (1928) reported three small passeriforms.

Possibly 15 stomachs contained eggshell or other remains of bird eggs; this was the most difficult item of food to identify with certainty, and three or four of these stomachs (including one presumed to contain over $28 \mathrm{~g}$ of egg remains) may not in fact have contained burd eggs. Since the hedgehog is more concerned with the content of the egg than 
its shell, however, one might expect that some stomachs of egg-eating hedgehogs would contain no shell at all. Identifying the amorphous mass of food in such a case would require biochemical or immunological tests.

Of the 19 occurrences of mammal prey in the present study, the almost complete adult Apodemus has already been mentioned. Another stomach contained a single molar and a little fur of a shrew (Soricidae, Sorex or Neomys) and one contained four teeth and some fur of a mole, Talpa europaea. The fur in the other stomachs was partially dentified with the help of the key by D a y (1966). In 9 cases, this came from Lagomorpha (Lepus or Oryctolagus) clearly suggesting the ingestion of carrion, perhaps trap bait. There were 4 stomachs with rodent fur, one of which also included a four-toed manus, indicative of a young mouse or vole, probably taken from a nest.

$\mathrm{Kalabukhov}$ (1929) recorded four mammals among the prey of his hedgehogs, including Mus musculus and Microtus sp. and Shilova-Kras ova (1952) reported five unidentified Muridae. Brockie (1959) and C a m p bell (1973a) each reported one hedgehog which had apparently been feeding on carrion hedgehog; though several of their samples also contained hedgehog hair, presumably obtained by groming.

Plant

The occurence of plant material in the stomach was puzzling, and it has been deliberately ignored until here. The hedgehog is frequently considered to be somewhat omnivorous, primarily on account of its bunodont dentition, hence a fair amount of plant food was expected. Indeed, plant material was recorded in at least 60 stomachs, a $44 \%$ occurrence. Yet in many cases this was evidently very finely chewed material from the gut of ingested caterpillars, or wisps of grass from ingested earthworms; in a number of other cases, there were just a few lengths of grass, probably picked up accidentally with prey animals. In only 15 stomachs was the quantity of vegetation at all notable; of these, three contained conifer "needles", eight had quantities of grass, three contained straw, and one had fibrous roots and fragments of dicotyledonous leaf. In none of these cases had the lengths of vegetable been chewed, nor had they apparently been digested. These stomachs were also notable for the fact that any animal food had been completely digested, leaving only odd feathers, fur or bits of exo-skeleton. It is felt that probably none of this vegetable material was ingested as food and Campbell (1973a) reached similar conclusions. Two stomachs contained bread, one of them about $8 \mathrm{~g}$ of it. 
Neither of the Russian workers considered vegetable food to be important, though $\mathrm{Kalabukhov}$ (1928) suggested that it might be eaten occasionally to quench thirst. $\mathrm{Brockie}$ (1959) mentions that $19 \%$ of the droppings he examined contained young clover shoots which had evidently been eaten deliberately, and he also mentions occurrences of apple and plum. Liu (1937) mentions one stomach which was entirely full of fruit (»jujubes" Zizyphus jujuba).

Unidentified Objects

Five stomachs in the present series contained items which could not be certainly identified, though they might if they had been sectioned and studied microscopically. Two appeared to be small pieces of meat and one a piece of bacon, there was a large quantity of translucent material, perhaps cartilage, in a fourth, and three small sheets of tough fibrous material in another.

\section{DISCUSSION}

It seems fairly clear from these results and those of other workers (Table 4) that the main prey of hedgehogs is invertebrate animals, more particularly those forms which occur just at ground level and are not too active - several authors have referred, for instance, to the virtual absence of grasshoppers from the prey. The major importance of caterpillars, scarabs, earthworms, and earwigs in both this study and Campbell's (1973a) is quite striking. It is also clear, as Rudge (1968) points out, that the hedgehog is, like other insectivores, something of an opportunist feeder, exploiting whatever food source is readily available. This was particularly evident in the present study where, while many hedgehogs had eaten many different items and none predominated in the stomach, others were found which had depended almost entirely on a single type of prey. Each of the main prey categories had formed the predominate prey for at least one hedgehog, and this is in accord with the importance of maggot's in Li u's (1937) hedgehogs, Melolontha to Shilova-Krassova's (1952), and gull chicks to those Kruuk (1964) studied. Campbell (1973a) emphasizes the predominance of Costelytra in the diet during its flight period.

However, the suggestion by R udg e (1968) that "taste« or "choice«, as demonstrated in cafeteria tests like those of $\mathrm{Dimelow}$ (1963) may not be very relevant to animals in the wild, bears some re-examination, in particular by comparison of his results on the diet of Sorex araneus and the present results for Erinaceus europaeus. Some differences are presumably directly related to the different sizes of the predators - 
the small harvestman Nemastoma lagubre and bibionid larvae would probably be too small for a hedgehog while scarabaeoid beetles would be too large for a shrew. The importance of Lithobius to the shrews but not the hedgehogs is presumably just a reflection of their speed of movement. The discrepancies between the occurrences of Diplopoda (in $40 \%$ of the hedgehogs but only $2 \%$ of the shrews) and Isopoda (in

Table 4

Percentage occurrence of prey items in hedgehog food according to different authors. * Kalabukhov's results are percentage of the number of individual prey, 582, which were found, hence should be compared with Table 1, column 4. $0=$ not recorded, $-=$ prey category not used.

\begin{tabular}{|c|c|c|c|c|c|c|c|}
\hline se & 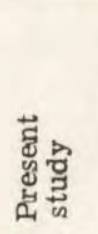 & 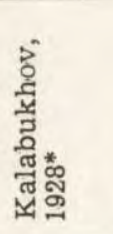 & 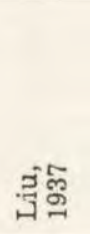 & 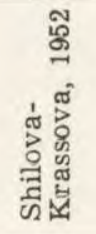 & 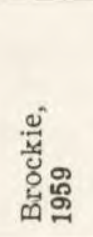 & 逑芯 & 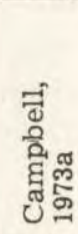 \\
\hline Lumbricidae & 35 & 0 & $\mathbf{0}$ & 0 & 35 & - & 22 \\
\hline Mollusca - slugs & 23 & 0 & 0 & 0 & 40 & - & 30 \\
\hline - snails & 4 & 0 & 0 & 0 & 36 & 21 & 0 \\
\hline Coleoptera - total & 74 & 85 & - & - & 34 & - & - \\
\hline Carabidae & 60 & 46 & - & 3 & - & - & 3 \\
\hline Scarabaeoidea & $21\}$ & 39 & - & 93 & - & - & 16 \\
\hline Others & $35\}$ & & - & 0.9 & - & - & 23 \\
\hline Diptera - Tipulidae (larvae) & 4 & 0 & - & 0 & 0 & - & - \\
\hline - other larvae & 7 & 0 & 79 & 0 & 2 & - & 3 \\
\hline - imagines & 12 & 0 & - & 0 & 13 & - & 32 \\
\hline Lepidoptera - larvae & 49 & 4.2 & - & 0.4 & 31 & - & 46 \\
\hline Dermaptera & 58 & 8.2 & - & 0 & 24 & - & 55 \\
\hline Hymenoptera & 15 & 0 & - & 0 & 12 & - & 4 \\
\hline "Other Insecta & 10 & - & 32 & 2 & c. 10 & 94 & c. 2 \\
\hline Chilopoda & 11 & & 0 & 0 & 33 & 0 & 0 \\
\hline Diplopoda & $40\}$ & 0.33 & 0 & 0 & - & 0 & 0 \\
\hline Isopoda & 2 & 0 & 0 & 0 & 11 & 0 & 17 \\
\hline Amphipoda & 0 & 0 & 0 & 0 & 0 & 18 & 0 \\
\hline Araneida & $18 !$ & & 0 & 0 & 0 & 0 & 33 \\
\hline Opiliones & $18 j$ & 0.17 & $\mathbf{0}$ & 0 & 15 & 0 & 17 \\
\hline Amphibia and Reptilia & 0 & 0.7 & 0 & 6 & 15 & 0 & 0 \\
\hline Aves - feather & 16 & 0.5 & 2 & 0.4 & 0 & 9 & 0 \\
\hline - eggs & 11 & 0 & 0 & 0 & 0 & 21 & 0 \\
\hline Mammalia & 12 & 0.7 & 6 & 2 & 15 & 0 & 0 \\
\hline Plant & 40 & 46 & 23 & 2 & 15 & 58 & c. 95 \\
\hline Other & 5 & 0 & 19 & 0 & 0 & 0 & - \\
\hline Numbers & 137 & $582^{*}$ & 47 & 262 & 90 & 33 & 230 \\
\hline
\end{tabular}

$2 \%$ of the hedgehogs but up to $20 \%$ of the shrews) are less easy to dismiss. The apparent absence of Forficula from the diet of the shrews, when it was present in $58 \%$ of the hedgehogs, is also puzzling. If a hedgehog can catch these items, a shrew certainly should be able to; the absence of diplopods and dermapterans from the shrews and of 
isopods from the hedgehogs seems to reflect genuine aversion. It is odd that the hedgehogs should find millipedes, and carabids, so acceptable, for the chemicals they produce certainly defend them against attacks by other invertebrates; yet Dimelow and Brockie suggest that these same chemicals might enable the hedgehog to find these prey more easily. Perhaps this is another part of the well known tolerance of hedgehogs to various kinds of ill treatment (snake venom, for instance).

The data presented here make an interesting comparison with the results obtained by Dimelow (1963), as they indicate both the strengths and weaknesses of "cafeteria tests". The relatively low level of acceptance of isopods in her tests matches their paucity of occurrence here, and confirms that hedgehogs genuinely avoid them. Likewise the fact that Lithobius often avoided her test hedgehogs corresponds well with their absence from the stomachs. On the other hand, her failure to test any larval Lepidoptera is seen in the light of the present results to be a major oversight.

Finally, it is worth enquiring whether these results have any relevance to the supposed usefulness of hedgehogs in gardens or its harmfulness to ground nesting birds. The Russian workers were particularly concerned about the significance of the hedgehog in the ecology of the state forests, and they had no doubt about the beneficient effects of its predation on, particularly, scarabaeoid beetles. Equally, in New Zealand, the importance in sheep farming country of consumption by hedgehogs of grass-feeding agrotid larvae might be considerable, and the larvae of the scarab Costelytra may also be a pest. C a mp bel1 (1973a) calculates that hedgehogs could eat between $5 \%$ and $40 \%$ of the adult scarab population. In this country, the value of the hedgehog in controlling forestry pests and pests of pasture land may well have been underestimated and would merit further study. The significant numbers of slugs eaten by suburban hedgehogs, and the importance of caterpillars in the diet of the hedgehogs examined here, certainly strengthens the traditional view of this animal as the gardener's friend.

It has been stressed already that the present results are somewhat equivocal on the issue of bird nest predation, though in finding invertebrate prey so important, they do not support the traditional emnity of game-keepers to the hedgehog. Yet there is enough evidence in the works of Kruuk (1964), Middletion (1935) and Jenkins (1961) to indicate that the hedgehog is nowhere near as serious a threat to game preservation as is popularly supposed. It is important to bear in mind the scale of losses due to hedgehogs and those due to other causes. For instance, Kruuk estimated that the hedgehogs at Ravenglass 
ate between 2 and $3 \%$ of the 8,000 broods per annum. Yet in 1962 , the foxes, in their »best " season, killed $825(5 \%)$ of the 16,000 adult birds, some 1,100 young birds (about $4 \%$ of the 8,000 broods) and a large number of eggs. In Middleton's (1935) study, the estate which lost $1.3 \%$ of its nests to hedgehogs, lost $33.8 \%$ to fox predation and $27.0 \%$ to accidents caused by farm work. In Jenkins' (1961) study, the hedgehog was the main predator, taking $3.4 \%$ of all the eggs laid, but mowing operations broke $3.1 \%$ and dogs and cats together accounted for $6.6 \%$. A x e $11(1956)$ is the only worker who considers that hedgehog predation has had a serious effect on the bird population under study. From 1952 to 1954, only 13 clutches of eggs of the Common Tern, Sterna hirundo, hatched out of 176 laid. Axell considered that nocturnal predators were responsible and blamed hedgehogs. However, the description he gives of the damaged eggs, and other circumstantial details, make it more likely that foxes were the culprits. While one could not argue that the hedgehog is harmless from these results, one wonders whether the level of damage done to game rearing is sufficient to warrant the attention it receives, and whether this level of damage is more important than the good the hedgehog may do in pest control.

Acknowledgements: I am very grateful to Dr. P. A. Morris, of the Department of Zoology, Royal Holloway College, University of London, for supplying the material to enable this work to be done, and for the background data on the hedgehogs which he provided. Through him, I must thank all the people who originally obtained the hedgehogs, not least the estate manager and gamekeepers of Estate L. I am also grateful to Dr. P. A. C a m p bell for a copy of her thesis. A number of people have considerably helped me with the identification of often very fragmentary prey. Among these are Dr. M. E. G. Evans, Dr. R. R. As k e w and Mr. J. G. B low e r of this department; Mr. A. B rindle and Mr. C. J o h ns o n, of the Department of Entomology, Manchester Museum; and Miss J. C h a tfield of the Department of Biology, City of Portsmouth College of Education, who was kind enough to check (and correct) my slug identifications. Naturally, any missed or mis-identifications remain my responsibility, but I hope I have justified the help they gave me, and I thank them for it.

\section{REFERENCES}

1. Axe11 H. E., 1956: Predation and protection at Dungeness bird reserve. Brit. Birds., 49: 193-212.

2. Blower J. G., 1958: British Millipedes. Linn. Soc. Lond. Synopses Br. Fauna, 11: $1-74$.

3. Bornebusch D. H., 1930: The fauna of the forest soil. Copenhagen.

4. Brockie R. E., 1959 Observations on the food of the hedgehog (Erinaceus europaeus L.) in New Zeland. N. Z. J. Sc., 2: 121-136.

5. Campbe11 P. A., 1973a: Feeding behaviour of the European hedgehog (Erinaceus europaeus L.) in a New Zeland pasture. Ph. D. thesis, Lincoln College, University of Canterbury.

6. Campbel1 P. A., 1973b: Feeding behaviour of the hedgehog (Erinaceus europaeus L.) in pasture land in New Zealand. Proc. N. Z. Ecol. Soc., 20: $35-40$. 
7. Cott H. B., 1951: The palatability of the eggs of birds: illustrated by experiments on the food preferences of the hedgehog (Erinaceus europaeus). Proc. zool. Soc. Lond., 121: 1-42.

8. Da y M. G., 1966: Identification of hair and feather remains in the gut and faeces of stoats and weasels. J. Zool., Lond., 148: 201-217.

9. Dimelow E. J., 1963: Observations on the feeding of the hedgehog (Erinaceus europaeus), Proc. zool. Soc. Lond., 141: 291-309.

10. Gerrard B. M., 1964: Lumbricidae (Annelida). Linn. Soc. Lond. Synopsis Br. Fauna, 6: $1-58$.

11. Herter K., 1965: Hedgehogs. London, Phoenix.

12. Jenkins D., 1961: Population control in protected partridges (Perdix perdix). J. Anim. Ecol., 30: 235-258.

13. Kalabukhov N. J., 1928: Uber die Nahrung des Igels im Nord-Kaukasus und in der Ukraine. Mitt Nordkaukas. Pflanzenschutzstation Rostow an Don, 4: 62-68. [In Russian, with German summary, seen in translation of the summary only].

14. Knight M., 1962: Hedgehogs. (London, Sunday Times).

15. Kruuk H., 1964: Predators and anti-predator behaviour of the black-headed gull (Larus ridibundus L.). Behaviour Suppl., 11: 1-129.

16. Lindeman W., 1952: Aus dem Leben des Igels. Schweiz. Natursh., 18: $39-42$.

17. Li u C. C., 1937: Notes on the food of Chinese hedgehogs. J. Mammal., 18: $355-357$.

18. Middlet on A. D., 1935: Factors controlling the population of the partridge (Perdix perdix) in Great Britain. Proc. zool. Soc. Lond., 105: 795-815.

19. M of $f$ a t C. B., 1900: Hedgehog food. Irish. Nat., 9: 50.

20. Morris B., 1967: Hedgehogs. [In: „The UFAW Handbook on the care and management of laboratory animals. ] London, Livingstone.

21. Morris P. A., 1970: A method for determining absolute age in the hedgehog. J. Zool., Lond., 161: 277-281.

22. Rudge M. R., 1968: The food of the common shrew Sorex araneus L. (Insectivora, Soricidae) in Britain. J. Anim. Ecol., 37: 565-581.

23. Shilova-Krassova S. A., 1952: The food of the hedgehog (Erinaceus europaeus L.) in southern woodlands. Zool. Z., 31: $944-947$. [Original in Russian, seen in translation].

24. Southern H. N., 1954: Tawny owls and their prey. Ibis $96: 384-510$.

25. Vasarhelyi I., 1960: Snail eating habits of vertebrates of the Bukk Mountains. Vertebr. hung., 2: 109-132.

Accepted, March 3, 1976

D. W. YALDEN

\section{POKARM JEŻA W ANGLII}

Streszczenie

Dokonano analizy zawartości 177 żołądków (z czego 40 było pustych) jeża zachodniego, Erinaceus europaeus Linna e us, 1758, zbieranych w różnych częściach 
Anglii. Wyniki wyrażono frekwencją występowania oraz udziałem ofiar w diecie a także procentowym ciężarem poszczególnych gatunków ofiar. Najczęstszym pokarmem, spotykanym w $60 \%$ żołądków, były Carabidae (Tabela 1). Następne w kolejności to Dermaptera i larwy Lepidoptera, Lumbricidae, Limacidae, Arionidae i Iulidae. Wagowo najważniejszym pokarmem były larwy Lepidoptera, Scarabeidae i Lumbricidae, stanowiące $55 \%$ diety (Ryc. 1). Kręgowce stanowiły tylko $15 \%$ diety. Dane te potwierdzają generalnie ustalony już przez innych autorów reżim pokarmowy jeża (Tabela 4). Stwierdzono ponadto, że istnieją zmiany diety zależne od płci i wieku zwierząt (Tabela 3 ) oraz pory roku (Tabela 2). 